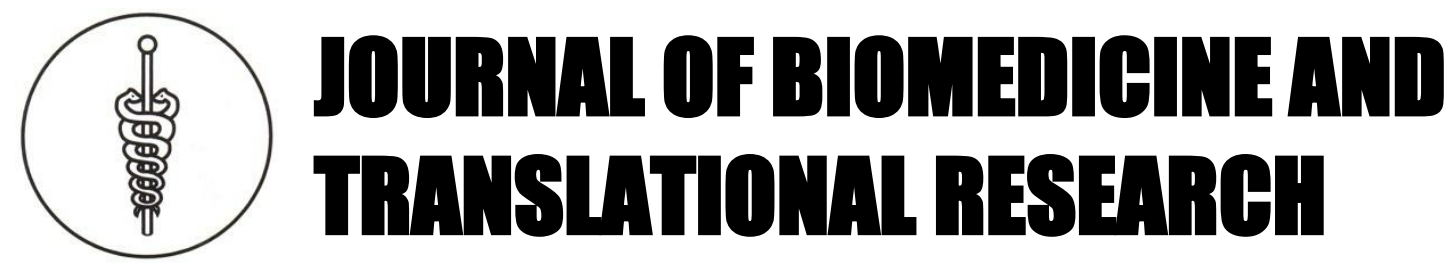

Copyright@2015 by Faculty of Medicine Diponegoro University and Indonesian Doctor Association, Central Java Region

\title{
The Expression of TTF-1 and CK-7 in the Diagnosis of Pleural Effusion Cytology Suspected Lung Adenocarcinoma
}

\author{
Patricia Diana Prasetiyo, IkaPawitra, IndraWijaya \\ Department of Pathological Anatomy Faculty of Medicine Diponegoro University Semarang.
}

\section{Article info}

History :

Received 4 March 2015

Accepted 28 Augsts 2015

Available 1 September 2015

\begin{abstract}
Background: Lung cancer is the major cause of death worldwide including Indonesia especially nonsmall cell lung cancer (NSCLC) group includingadenocarcinoma, squamus carcinoma (SqCCA) and large cell lung cancer (LCLC).Incidence of lung adenocarcinoma continues to rise up about $40 \%$ of all NSCLC in January 2012Desember 2013; and 15\% of pleural effusion associated with malignancies. To confirm the diagnosis, monoclonal antibody anti -TTF-I and CK-7 are currently used to identify types of lung tumors adenocarcinoma, especially when cytomorfologically is doubtful.

Methods: The design of the study wasa descriptive observational, that included individuals who were hospitalized at Dr. Kariadi TeachingHospital in Semarang, confirmed by thorax X-ray with diagnosis of suspected lung malignancy, between January 2012 - 2013. The expression of TTF-I and CK-7 Were analysed using immunohistochemistry.
\end{abstract}

Result: A total of 20 samples subjected to Pearson correlation test with result of $P$ value $=<0,00 \mathrm{I}$ and $r=0,867$. The highest expression TTF-I in the all study sample wasadenocarcinoma (73.3\%) and highest expression CK-7 was also adenocarcinoma (68.6\%).

Conclusion:The expressionof TTF-I and CK-7 on tissue samples can be used to confirmadenocarcinoma malignancy on the cytological sample of suspected malignant pleural effusion

Keywords: TT-I, CK-7, adenocarcinoma, pleural effusion, nonsmall cell lung cancer (NSCLC)

\section{INTRODUCTION}

Lung cancer is a major cause of death in the world, including Indonesia, especially non-small cell lung cancer (NSCLC) including adenocarcinoma, squamous carcinoma (SqCCA) and large cell lung cancer (LCLC) that occurs in about $80 \%$ of all lung cancer. ${ }^{1,2}$ Recently, the incidence rate of lung adenocarcinoma is increasingabout $40 \%$ ofall non-small cell lung cancer (NSCLC). ${ }^{3}$ Lung cancer in Indonesia was ranked fourth of all cancers, Data fromMinistry of Health shows the number of cancer cases in Indonesia reached to $6 \%$ of the population. ${ }^{4,5}$
Pleura effusion is a condition where there is an excessive fluid in the pleural cavity, $15 \%$ of the cases are associated with malignancy provenby the presence of malignant cells in cytological examination from pleural effusion or biopsyof the lung. This malignancy could be categorized intoadenocarcinoma, squamous cell carcinoma, small cell carcinoma, mesothelioma malignancy, neuroendocrin tumor. ${ }^{6,7}$ The expresions of TTF-1 and CK-7 antibodiesare used to differentiate between adenocarcinoma with other carcinoma.TTF-1 and $\mathrm{CK}-7$ are available in the market and relatively inexpensive. Yue-Chiu Su (2006) showed that TTF-1 
antibody and CK-7 can differentiate adenocarcinoma lung primer and metastatic. TTF-1 is a sensitive marker for pulmonary and thyroid adenocarcinoma. TTF-1 immunohistochemistry is a very sensitive and highly specific method in the differential diagnosis of primary and metastatic lung adenocarcinomas and should be used in the everyday clinical practice. , $^{8,9,10}$

The examination by immunocytochemistry staining for Thyroid transcription factor-1 (TTF-1), Cytokeratin 7 (CK 7), Cytokeratin 20 (CK 20), are important to differentiate among those type of cancers (Kingshuk $\mathrm{R}$ et al, 2013) ${ }^{8,9}$.

This study using a cytology block of pleural effusion. To diagnosemalignant cells in the cytology preparations sometimes difficult to distinguish between the benign and malignant cells, lead to misdiagnosis. Therefore, the usage of TTF- 1 and CK-7 antibodies to identify types of lung adenocarcinoma is very useful to determine whether the cells are malignant or not.This research usingTTF-1 and CK-7 monoclonal antibody to differentiate specifically between adenocarcinoma with other carcinoma, without increasing cost of examination.

\section{METHODS}

This study was a cross sectional design. This study population included individuals admitted to the Dr.Kariadi TeachingHospital in Semarang that had been thorax X-ray with diagnosis of suspected malignant pleural effusion. Cytological examination of Pleural effusion performed using immunohostochemistry method. The number of research sample were consecutive population who met the inclusion criteria. The Expression of TTF-1 positive was brown staining at the nuclei where as CK7 positive was brown staining in the cytoplasm, the color intensity and percentage are calculated using Allred Score ${ }^{8}$. All met inclusion criteria patients had to sign an informed consent form to approve their participation, and the research proposal have been approved by The Ethical Review Board of the Institution .

\section{RESULT AND DISCUSSION}

A total of 20 samples with suspected malignant pleural effusion met the inclusion criteria were included in this study.

Table 1. Descriptive Diagnosis of TTF-1 and CK-7 in 20 patients.
Table 1 shows the expression of TTF-1 maximum value on sample of suspected adenocarcinoma with score 7 , while minimum value on sample of suspected squamos cell carcinoma with score 0 . Whereas CK-7 shows maximum value on sample of suspected adenocarcinoma with score 8 , while minimum value on squamos cell carcinoma with score 0 .

Table 2. Pearson Correlation Test Result

\begin{tabular}{llll}
\hline Variable & Mean \pm SD & $\mathrm{R}$ & $\mathrm{P}$ \\
\hline TTF-1 & $3.85 \pm 2.254$ & & \\
CK-7 & $4.45 \pm 2.460$ & 0.867 & $<0.001^{*}$ \\
\hline
\end{tabular}

Table2. shows Pearson correlation $\mathrm{p}$ value $=<0.001$ and $r=0.867$, so we conclude that there is a significant relationship between expressions of TTF-1 to CK-7 with very strong power of positive relationship

Table 3. Percentage TTF-1 and CK-7

\begin{tabular}{|c|c|c|c|c|c|}
\hline \multirow{3}{*}{ Diagnosis } & \multicolumn{4}{|c|}{ TTF-1 } & \multirow{3}{*}{$\mathbf{p}$} \\
\hline & \multicolumn{2}{|c|}{ Positive } & \multicolumn{2}{|c|}{ Negative } & \\
\hline & $\mathbf{n}$ & $\%$ & $\mathbf{n}$ & $\%$ & \\
\hline $\begin{array}{l}\text { Suspected } \\
\text { Adenocarcinoma }\end{array}$ & 11 & 73.3 & 0 & 0 & \multirow[t]{4}{*}{0.009} \\
\hline Suspected & \multirow[b]{2}{*}{2} & \multirow[b]{2}{*}{14.4} & \multirow[b]{2}{*}{1} & \multirow[b]{2}{*}{20} & \\
\hline $\begin{array}{l}\text { Adenosquamus cell } \\
\text { carcinoma }\end{array}$ & & & & & \\
\hline $\begin{array}{l}\text { Suspected Squamus cell } \\
\text { carcinoma }\end{array}$ & 2 & 12.3 & 4 & 80 & \\
\hline \multirow{3}{*}{ Diagnosis } & \multicolumn{4}{|c|}{ CK-7 } & \multirow{3}{*}{$\mathbf{P}$} \\
\hline & \multicolumn{2}{|c|}{ Positive } & \multicolumn{2}{|c|}{ Negative } & \\
\hline & $\mathbf{n}$ & $\%$ & $\mathbf{n}$ & $\%$ & \\
\hline Suspected Adenocarcinoma & 11 & 68.8 & 0 & 0 & 0.003 \\
\hline $\begin{array}{l}\text { Suspected Adenosquamus cell } \\
\text { carcinoma }\end{array}$ & 3 & 18.8 & 0 & 0 & \\
\hline $\begin{array}{l}\text { Suspected Squamus cell } \\
\text { carcinoma }\end{array}$ & 2 & 12.5 & 4 & 100 & \\
\hline
\end{tabular}

\begin{tabular}{|c|c|c|c|c|c|c|c|}
\hline \multicolumn{2}{|c|}{ Diagnosis } & \multirow{2}{*}{$\frac{\mathrm{n}}{11}$} & \multirow{2}{*}{$\begin{array}{l}\text { Mean } \\
5.55\end{array}$} & \multirow{2}{*}{$\begin{array}{l}\mathrm{SD} \\
1.036\end{array}$} & \multirow{2}{*}{$\begin{array}{l}\text { Median } \\
6.00\end{array}$} & \multirow{2}{*}{$\frac{\text { Min }}{4}$} & \multirow{2}{*}{$\frac{\operatorname{Max}}{7}$} \\
\hline TTF-1 & Suspected Adenocarcinoma & & & & & & \\
\hline & Suspected Adenosquamus cell carcinoma & 3 & 2.67 & 0.577 & 3.00 & 2 & 3 \\
\hline & Suspected Squamus cell carcinoma & 6 & 1.33 & 1.506 & 1.00 & 0 & 3 \\
\hline \multirow[t]{2}{*}{ CK-7 } & Suspected Adenocarcinoma & 11 & 6.00 & 1.096 & 6.00 & 4 & 8 \\
\hline & Suspected Adenosquamus cell carcinoma & 3 & 4.67 & 2.082 & 4.00 & 3 & 7 \\
\hline
\end{tabular}


On Table 3, result of percentage expression of TTF-1 in all sample was highest on suspected positive adenocarcinoma was $73.3 \%$ and lowest was on sample of suspected squamus cell carcinoma of $12.3 \%$. While percentage of expression of CK-7 in all sample was highest on suspected positive adenocarcinoma of $68.8 \%$ and lowest on sample of suspected squamus cell carcinoma of $12.5 \%$.

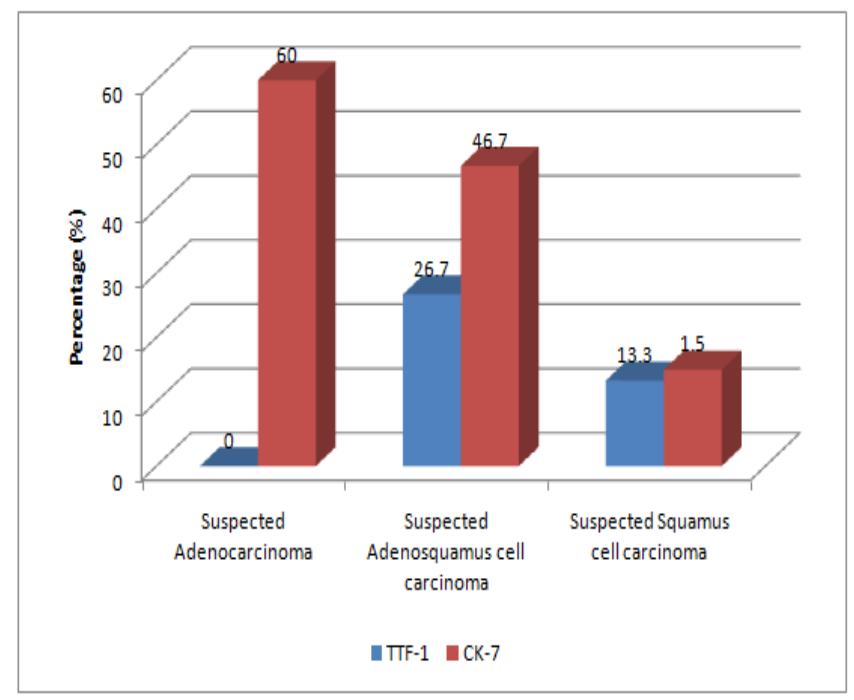

Figure 1.The expression of TTF-1 and CK-7 in all patients (in percentage).

The graphs show the expression of TTF-1 and CK-7 are dominant in patients with suspected lung adenocarcinoma, meanwhile less expressed in patients suspected lung squamous cell carcinoma.

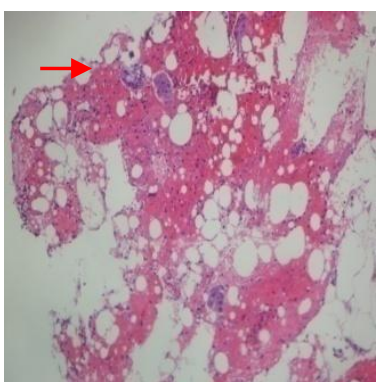

A. Magnification 100X, Haematoxylin Eosin, shows group of cancer cell (arrow)

Figure 2. Malignant cell in Haematoxylin Eosin and Pappanicolau stained
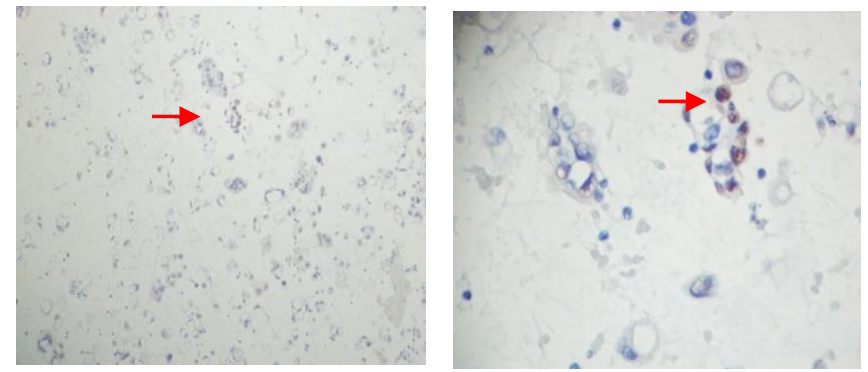

Figure 3. Malignant cell stained TTF-1 positive, brown staining on the core of malignant cell(arrow)
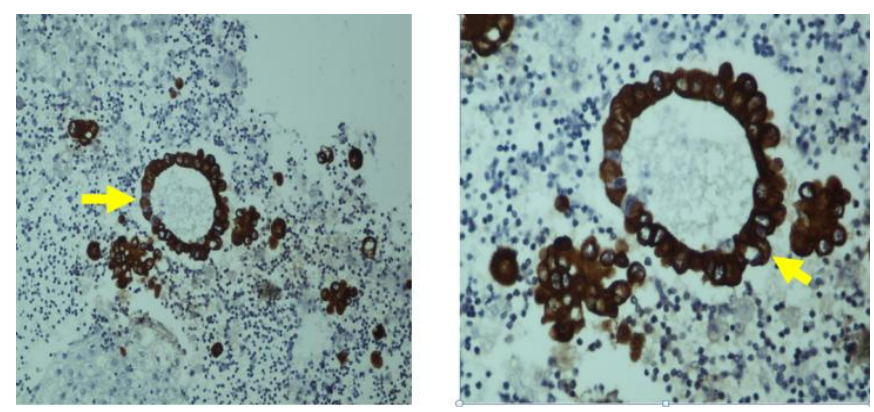

\section{A. Magnification $100 X$ CK-7 staining}

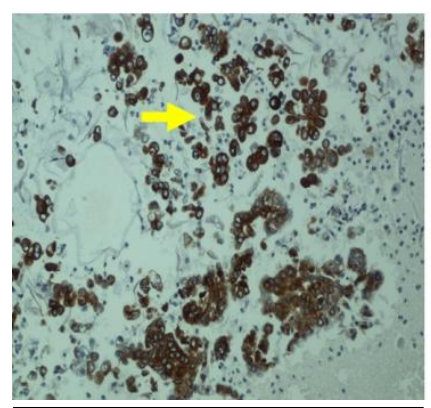

C. Magnification 100X, CK-7 staining
B. Magnification 400X, CK-7 staining

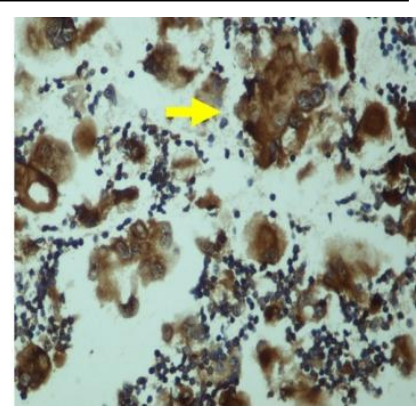

D. Magnification400X, CK-7 staining
Figure 4. Microscopic staining of CK-7 Positive, arrow showed cell stained CK-7 positive, brown staining on the cytoplasm of malignant cell (arrow)

Lung cancer is the leading cause of death worldwide. WHO classification of 2004, there are seven main histological types of lung tumors epithelial malignancy and over 20 variants. Lung epithelial tumor of non-small cell lung carcinoma, includes: adenocarcinoma, squamous cell carcinoma, large cell and large cell undifferentiated carcinoma. ${ }^{13}$ Several studies have shown a tendency of adenocarcinoma type to metastasize faster, and its incidence continues to increase. Adenocarcinoma are found mainly in Asian women $(72 \%$ of cancer cases in Japan, $65 \%$ in Korea, $61 \%$ in China Singapore). The differences in 
histological types are mostly affected by variations of smoking habits, while in United States the incidence of adenocarcinoma of the lung is $38 \%$ of all lung cancers. $11,12,13$

Table 3 shows the expression of TTF-1 in the sample suspected adenocarcinoma was $73.3 \%$ in the sample suspected squamous cell carcinoma was $13.3 \%$, whereas, the expression of CK-7suspected adenocarcinoma showed $68.8 \%$ and in the sample of squamous cell carcinoma was $12.5 \%$. the results indicateing that the expression of TTF-1 and CK-7 are more dominant on suspected adenocarcinoma than the other. This results is almost the same with the previous study on the expression of TTF-1 and CK-7, by YueChiu Su (2006), They found that TTF-1 antibody and CK-7 can be used to differentiate adenocarcinoma lung primer and metastatic ${ }^{14,15}$.

Primary lung malignancy contain Surfactant protein A (SPA) which is a major component of surfactant and Clara cell, which is synthesized and excreted in the lung alveoli by type II pneumocyte. In pleural effusion caused by primary lung malignancy, it contains high concentration of Surfactant protein A (SPA) especially in lung adenocarcinoma, that then will express TTF-1. Evidences indicated that TTF-1 is very important in the development of lung embryogenesis and increased expression in Clara cells and type II pneumocyte. ${ }^{15,16}$

In this study, the expression of TTF-1 in adenocarcinoma was $73.3 \%$, adenosquamus $14.4 \%$, while the squamus cell carcinoma contain a little Surfactant protein A (SPA) so that in this study the expression is only $12.2 \%$. According to the previous studies, TTF-1 expressing specific tissue indicating the specific molecular biomarkers in primary tumors of lung adenocarcinoma. ${ }^{13}$

In the group of $\mathrm{CK}-7$ the most dominant expression was in the samples of suspected lung adenocarcinoma by $68.8 \%$ Cytokeratin-7 (CK7) is a human protein that encodes the gene KRT7, a type II keratin. Cytokeratin 7 is a protein that mainly located in the lung and breast organs. In research conducted by Peiguo Chu stated that the expression of CK-7 in lung adenocarcinoma was $100 \%$ while the squamous cell carcinoma of lung was $0 \%$ in all cases. ${ }^{16}$ Although CK-7 is able to identify lung adenocarcinoma, but it can also be positive in the metastasis of other tumors. CK-7 and CK-20 are often combined, especially when suspected of metastases from colorectal tumors (intestinal tumors), in metastatic colorectal tumors in the lung $\mathrm{CK}-7$ is negative while CK-20 is positive, therefore clinical examination is very important to predict the primary or secondary tumor. ${ }^{16,17}$

The use of antibody TTF-1 and CK-7 to identify types of lung tumors adenocarcinoma can be used to confirm a doubtful cytomorfological that can differentiate between malignant or not. ${ }^{18}$ From the discussion above we can conclude that the expression of TTF-1 and CK-7 protein are overexpressed in samples of lung adenocarcinoma. ${ }^{19,20}$

\section{CONCLUSION}

TTF-1 and CK-7 espressions can be used to detect malignancy especially lung adenocarcinoma using cytology preparation. The expression of TTF-1 andCK7 is very strong positive predictor $(\mathrm{p} \leq 0.001$ and $\mathrm{r}=$ 0.867 ) and biomarker for lung adenocarcinoma

\section{SUGGESTION}

Using other specific antibody immune histo chemistry as the marker of lung adeno carcinoma is recommended to avoid secondary tumor

\section{ACKNOWLEDGMENTS}

We thank dr. Dik Puspasari, Pathologits, and Udadi Sadhana, Pathologist who participating in this research. Appreciated also to Mr. Arifin and Mrs. Wiwik for the help in laboratory works.

\section{REFERENCES}

1. Apdani R, Karakteristik Penderita Kanker Paru Yang Dirawat Inap Di Bangsal Paru Rumah Sakit Umum Dr. Soedarso Pontianak Periode 1 Januari 2006 - 31 Desember 2010. Skripsi . Pontianak: Program Studi Pendidikan Dokter Fakultas Kedokteran Dan Ilmu Kesehatan Universitas Tanjungpura, 2011.

2. Diederich S. Focus On: Lung Cancer.InCT screening for lung cancer . Cancer Imaging.; 8:2426. 2008

3. Fatima N, Cohen C, Lawson D.M.T, Siddiqui M.T. TTF-1 and Napsin A Double Stain. Cancer Cytopathology; 25:127-32.2011

4. Flieder D.B. Screen-Detected Adenocarcinoma of the Lung. In Practical Points for Surgical Pathologists Am J Clin Pathol;119(1):39-57, 2003

5. Ferlay J, Autier P, Boniol M, Heanue M, Colombet M,Boyle P. Estimates of the cancer incident and mortality in Europe in 2006.Ann Oncol;18:581-92,. 2007

6. Hecht J. L, Pinkus,J.L, Weinstein L.J, Pinkus G.S. The Value of Thyroid Transcription Factor-1 in Cytologic Preparations as a Marker for Metastatic Adenocarcinoma of Lung Origin. Am J Clin Pathol;116:483-488,2001 
7. John C, Ruckdeschel, Myths \&Facts about lung cancer: What you need to know. USA.Bryson Biomedical. 2006

8. Kingshuk Roy Choudhury, Kevin J. Yagle, Paul E. Swanson, Kenneth A. Krohn,Joseph G. Rajendran. A Robust Automated Measure of Average Antibody Staining in Immunohistochemistry Images. Journal of Histochemistry \& Cytochemistry. Volume 58(2): 95 ,2010

9. Kanker Paru. dalam Pedoman Diagnosis \&Penatalaksanaan Di Indonesia. : Perhimpunan Dokter Paru Indonesia. 2013

10. Kadara H, Behrens C, Yuan P, Solis L, Liu D, Xuemin $\mathrm{Gu}$, et al. A five-gene and correspondingprotein signature for stage-Ilung adenocarcinoma prognosis. Clin Cancer Res.2010.

11. Lam B, Lam W.K, Lam C.L, Ooi G.C, Ho JCM, Wong M.P.et,al. Adenocarcinoma of the lung in Chinese patients: a revisit and some perspectives from the literature. Postgrad Med J 2001;77:70812

12. Lung Cancer, Lung Adenocarcinoma, College of American Pathologists, Dec.. Available www.cancer.gov, 2006

13. Lin C.C, Chen L.C, Tseng V.S, Yan J.J, Lai W.W, $\mathrm{Su}$ W.P. Malignant pleural effusion cells show aberrant glucose metabolism gene expression Division of Hematology/ Oncology Department of Internal Medicine Hospital and College of medicine, National Cheng Kung University College. Taiwan.2010

14. Mignotte H.N, Guillem P, Vesin A, Toffart A.C, Colonna M, Bonneterre V, et al. Primary lung adenocarcinoma: characteristics by smoking habit and sex. Eur Respir J.; 38: 1412-1419, 2011.

15. Persatuan Ahli Penyakit Dalam. Buku Ajar Ilmu Penyakit Dalam jilid2. Jakarta : Balai Penerbit FK UI; VII:915-18,1996

16. Parkin M Tyczynski J.E, Boffetta P Samet J, Shields P, Caporaso N, Lung cancer epidemiology and etiology. In . Travis W.D, Brambilla E, Hermelink H.K.M, Harris C.c,Editors. Tumours of the Lung, Pleura, Thymus and Heart. World Health Organization Classification of Tumours. 2004.

17. Pao W, Vincent A, Miller, Katerina A. Politi, Gregory J, et al.Acquired Resistance of Lung Adenocarcinomas to Gefitinib or Erlotinib Is Associated with a Second Mutation in the EGFR Kinase Domain. PLoS Medicine.;2(3):225-33, 2005

18. Remmelink M. New Lung Adenocarcinoma Classification In Daily Practice. 2012.
19. Syahruddin E, Pratama AD, Arief N. A retrospective study : clinical and diagnostic characteristics in advanced stage of lung cancer patients with pleural effussion in persahabatan hospital 2004 - 2007. J Respir Indo;30:146151,2010

20. William D. Travis, Brambilla E; Noguchi M, Andrew G, Nicholson. Diagnosis of Lung Cancer in Small Biopsies and Cytology. In Implications of the 2011 International Association for the Study of Lung Cancer/ American Thoracic Society/ European Respiratory Society Classification. Arch Pathol Lab Med.;137:668-684, 2013 